\title{
UPAYA PENGELOLAAN LINGKUNGAN SEBAGAI UPAYA PENINGKATAN KUALITAS LINGKUNGAN HIDUP HULU SUNGAI SELATAN KALIMANTAN SELATAN
}

\author{
Sri Subekti ${ }^{1}$, Eny Apriyati ${ }^{2}$, Shintawati ${ }^{3}$ \\ ${ }^{1,2,3}$ Universitas Pandanaran Semarang \\ Jl. Banjarsari Barat No. 1 Semarang
}

Email: bek1_04@yahoo.com

\begin{abstract}
ABSTRAK
Meningkatkan kualitas lingkungan hidup menjadi penting tujuan dari upaya pengelolaan lingkungan hidup ini adalah mengingat kerusakan lingkungan hidup mulai berdampak dalam skala lokal dan berkontribusi terhadap skala global. Tujuan Pengelolaan Lingkungan Hidup adalah menyajikan data dan informasi sebagai referensi utama dalam pengambilan kebijakan, perencanaan, penelitian, pembelajaran dan pengetahuan atau wawasan pada umumnya Metodologi yang digunakan adalah menggunakan metode Participatory Approaches and Expert Opinion. Isu-isu lingkungan hidup diperoleh melalui pengumpulan informasi yang dilakukan oleh kelompok pemangku kepentingan (stakeholder) dan pendapat pakar (expert opinion) melalui forum Focus Group Discussion(FGD). Dari permasalahan di atas dan sebagai upaya pengelolaan lingkungan maka simpulan yang dihasilkan adalah: 1. Masih adanya penggunaan air sungai untuk kegiatan Mandi Cuci Kakus (MCK) sehingga diperlukan suatu upaya untuk /mengurangi pemakaian air sungai untuk aktivitas MCK, atau dengan kata lain menghapuskan atau mengurangi jumlah jamban di atas sungai. Menghimbau masyarakat untuk tidak lagi membangun/ menggunakan jamban di atas sungai, dan menghimbau masyarakat yang tinggal di daerah sempadan sungai untuk membangun fasilitas MCK dengan menggunakan septic tank, ataupun IPAL komunal. Mengurangi/menghentikan kebiasaan masyarakat untuk membuang limbah baik limbah padat maupun limbah cair ke sungai. Menghimbau masyarakat, khususnya petani untuk menggunakan pupuk kimia/buatan secara lebih bijaksana, atau sesuai dengan keperluan dan tidak berlebihan. Bahkan, jika memungkinkan, mengganti pupuk kimia dengan pupuk alami seperti pupuk kandang atau kompos.
\end{abstract}

Kata kunci : pengelolaan, peningkatan, kualitas, lingkungan

PENDAHULUAN

Setiap wilayah memiliki karakteristik lingkungan hidup yang berbeda, baik dari sisi sumber daya alam yang tersedia maupun cara masyarakatnya untuk mengelola lingkungan itu sendiri, seperti halnya dengan Kabupaten Hulu Sungai Selatan. Kabupaten Hulu Sungai Selatan memiliki keragaman konfigurasi fisik lingkungan yang dibagi menjadi tiga kawasan, yaitu: pegunungan, dataran dan pesisir. Selain menjadi modal bagi pembangunan daerah, karakteristik fisik wilayah juga menyimpan kerentanan terhadap kerusakan lingkungan sebagai akibat pengelolaan yang tidak optimal yang akan berakibat pada penurunan daya dukung lingkungan. Masalah daya dukung fisik wilayah dapat berupa konflik pemanfaatan ruang sehingga berdampak pada kerusakan lingkungan.
Menurut Undang-Undang nomor 32 tahun 2009 tentang Perlindungan dan Pengelolaan Lingkungan Hidup bahwa setiap orang berhak atas lingkungan hidup yang baik dan sehat sebagai bagian dari hak asasi manusia. Untuk mencapai kondisi lingkungan yang berkualitas baik maka, setiap orang berkewajiban memelihara kelestarian fungsi lingkungan hidup serta mengendalikan pencemaran dan/atau kerusakan lingkungan hidup.

Meningkatkan kualitas lingkungan hidup menjadi penting tujuan dari upaya pengelolaan lingkungan hidup ini adalah mengingat kerusakan lingkungan hidup mulai berdampak dalam skala lokal dan berkontribusi terhadap skala global. Penyebabnya adalah pembangunan dan industrialisasi yang selama ini kurang mempertimbangkan aspek lingkungan hidup. Dengan memperhatikan Sustainable Development 
Goals (SDGs) sebagai agenda global yang fokus menangani masalah sosial, ekonomi, dan lingkungan, maka Pemerintah Kabupaten Hulu Sungai Selatan berkomitmen untuk meningkatkan pembangunan daerah yang memperhatikan kualitas lingkungan hidup.

Kabupaten Hulu Sungai Selatan yang terletak pada posisi 02029'58' sampai dengan 02056'10" LS dan 114051'19', sampai dengan 114006'19' BT, berdasarkan Penataan Ruang sebagaimana tercantum dalam Perda Kabupaten Hulu Sungai Selatan Nomor: 15 Tahun 1996, Kabupaten Hulu Sungai Selatan memiliki luas wilayah sebesar $180.494 \mathrm{Ha}$ atau setara dengan $1.804,94 \mathrm{Km} 2$. Luas kawasan hutan di Kabupaten Hulu Sungai Selatan sesuai SK. Menhut No.435/Menhut-II/2009 : 55.345,52 Ha terdiri dari Hutan Produksi Tetap : 12.461,12 Ha, Hutan Lindung : 23.919,52 Ha, Hutan Swaka Cagar Alam : 240,43 Ha , Hutan Konversi : 18.724,45 Ha. Wilayah KPHL Model Hulu Sungai Selatan ditetapkan berdasarkan Surat Keputusan Menteri Kehutanan Nomor :SK.750/Menhut-II/2012 tanggal 26 Desember 2012 tentang Penetapan Wilayah Kesatuan Pengelolan Hutan Lindung Model Hulu Sungai Selatan yang terletak di Kabupaten Hulu Sungai Selatan Provinsi Kalimantan Selatan seluas \pm 32.803 (Tiga Puluh Dua Ribu Delapan Ratus Tiga) Hektar dengan rincian :Hutan Lindung seluas $\pm 21.211 \mathrm{Ha}$, Hutan Produksi Terbatas seluas \pm 52 Ha, Hutan Produksi seluas $\pm 11.503 \mathrm{Ha}$.

Lahan kritis merupakan permasalahan terhadap lahan yang keadaan fisiknya demikian rupa sehingga lahan tersebut tidak dapat berfungsi secara baik sesuai dengan peruntukkannya sebagai media produksi maupun sebagai media tata air. Akibat lahan kritis mengakibatkan daya resap tanah terhadap air menurun sehingga kandungan air tanah berkurang yang mengakibatkan kekeringan pada waktu musim kemarau, terjadinya arus permukaan tanah pada waktu musim hujan yang mengakibatkan bahaya banjir dan longsor menurunnya kesuburan tanah, dan daya dukung lahan serta keanekaragaman hayati. Apabila kondisi tersebut diatas dibiarkan terus berlangsung maka pada akhirnya akan menyebabkan produktifitas lahan dan produksi pertanian menurun sehingga pada akhirnya akan menyebabkan kemiskinan masyarakat, khususnya masyarakat tani.

Tujuan Pengelolaan Lingkungan Hidup adalah menyajikan data dan informasi sebagai referensi utama dalam pengambilan kebijakan, perencanaan, penelitian, pembelajaran dan pengetahuan atau wawasan .

\section{METODOLOGI}

Metodologi yang digunakan adalah menggunakan metode Participatory Approaches and Expert Opinion. Isu-isu lingkungan hidup diperoleh melalui pengumpulan informasi yang dilakukan oleh kelompok pemangku kepentingan (stakeholder) dan pendapat pakar (expert opinion) melalui forum Focus Group Discussion(FGD).

\section{HASIL DAN PEMBAHASAN}

Pengelolaan kawasan hutan khususnya Hutan Lindung di Kabupaten Hulu Sungai Selatan belum dapat dilaksanakan secara efektif disebabkan beberapa faktor antara lain keterbatasan sumber daya dan sumberdana yang tersedia serta kelembagaan yang memadai. Keberadaan KPHL Model Hulu Sungai Selatan sebagai sarana pencapaian pengelolaan hutan lestari di Kabupaten Hulu Sungai Selatan sejalan dengan komitmen Pemkab Hulu Sungai Selatan untuk mewujudkan tata kelola hutan yang sesuai fungsi dan peruntukkan serta mewujudkan proses transpormasi dan desentralisasi kelembagaan pengelolaan hutan.

Perubahan penggunaan lahan berupa penurunan luas sawah dari 51.608 ha menjadi 51.158 ha, jumlah tepatnya adalah seluas 450 ha. Sawah merupakan guna lahan terbesar kedua di Kabupaten Hulu Sungai Selatan setelah pertanian lahan kering.

Berdasarkan data BPS Kabupaten Hulu Sungai Selatan dalam Angka Tahun 2017 bahwa penggunaan lahan di Kabupaten Hulu Sungai Selatan terdiri dari 8 jenis, yaitu: kampung 2,86 \%, sawah 24,54\%, ladang 4,98\%, kebun campuran $0,97 \%$, kebun karet 6,04 \%, padang (semak, alang dan rumput) 29,82 $\%$, hutan $30,82 \%$ dan rawa $0,11 \%$.

Kawasan resapan air terdapat di semua kawasan hutan lindung meliputi: 
a. Kecamatan Loksado seluas kurang lebih 7.490 (tujuh ribu empat ratus sembilan puluh) hektar;

b. Kecamatan Padang Batung seluas kurang lebih 750 (tujuh ratus lima puluh) hektar; dan

c. Kecamatan Telaga Langsat seluas kurang lebih 250 (dua ratus lima puluh) hektar.

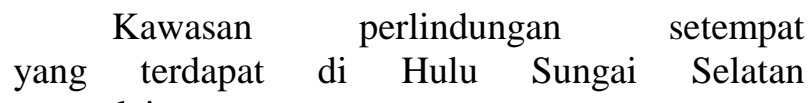
antara lain:

a. Kawasan perlindungan sempadan sungai

b. Kawasan perlindungan sekitar danau, meliputi:

- Danau Bangkau di Kecamatan Kandangan seluas kurang lebih 615 (enam ratus lima belas) hektar;

- Danau Paharangan di Kecamatan Daha Utara seluas kurang lebih 8 (delapan) hektar;

- Danau Pantai Ulin di Kecamatan Simpur seluas kurang lebih 5 (lima) hektar;

- Danau Muning Dalam di Kecamatan Daha Selatan seluas kurang lebih 5 (lima) hektar;

- Danau Bago Tanggul di Kecamatan Kalumpang seluas kurang lebih 6 (enam) hektar; dan

- Danau Bajayau Lama di Kecamatan Daha Barat seluas luas kurang lebih 6 (enam) hektar.

c. Kawasan ruang terbuka hijau (rth) perkotaan seluas kurang lebih 2.580 (dua ribu lima ratus delapan puluh) hektar atau $30 \%$ dari keseluruhan kawasan perkotaan

Kawasan Suaka Alam, Pelestarian Alam dan Cagar Budaya

a. Kawasan suaka alam seluas kurang lebih 1.240 (seribu dua ratus empat puluh) hektar beradadi Cagar Alam Gunung Kantawan

b. Kawasan pelestarian alam berupa kawasan perlindungan mutlak habitat dan populasi ikan yang diperbolehkan ditangkap hanya sebagai keperluan penelitian, meliputi:

- Reservaat Danau Bangkau di Desa Bangkau Kecamatan Kandangan dengan zona inti seluas kurang lebih 11 (sebelas) hektar;

- Reservaat sungai Jarum di Desa Bangkau Kecamatan Kandangan dengan zona inti seluas kurang lebih 100 (seratus) hektar;

- Kawasan Rawa Simpur di Tanggul Desa Pantai Ulin Kecamatan Simpur dengan zona inti seluas kurang lebih 5 (lima) hektar;

- Kawasan Bago Tanggul di Desa Bago tanggul Kecamatan Kalumpang dengan zona inti seluas kurang lebih 5 (lima) hektar;

- Kawasan Bajayau Lama di Desa Bajayau Lama Kecamatan Daha Barat dengan zona inti seluas kurang lebih 5 (lima) hektar; dan

- Kawasan Muning Dalam di Desa Muning Dalam Kecamatan Daha Selatan dengan zona inti seluas kurang lebih 6 (enam) hektar.

- Zona perikanan berkelanjutan berada di luar zona inti seluas kurang lebih 730 (tujuh ratus tiga puluh) hektar, dan

- Zona pemanfaatan berada di luar zona inti dan zona perikanan berkelanjutan dengan luas kurang lebih 487 (empat ratus delapan puluh tujuh) hektar.

- Kawasan cagar budaya dan ilmu pengetahuan, meliputi: 
- Rumah Adat Banjar Bubungan Tinggi di Kecamatan Daha Selatan;

- Masjid Su'ada di Kecamatan Simpur;

- Benteng Madang di Kecamatan Padang Batung;

- Tugu/Monumen Teks Proklamasi Gubernur Tentara ALRI Divisi IV Pertahanan Kalimantan 17 Mei 1949 di desa Ni'ih;

- Makam Tumpang Talu di Kecamatan Kandangan

- Rumah Bersejarah H.Abdul Kadir di Kecamatan Padang Batung

Pengelolaan kawasan

khususnya Hutan Lindung di

Kabupaten Hulu Sungai Selatan belum

dapat dilaksanakan secara efektif

disebabkan beberapa faktor antara

lain keterbatasan sumber daya dan

sumberdana yang tersedia serta

kelembagaan yang memadai.

Keberadaan KPHL Model Hulu

Sungai Selatan sebagai sarana

pencapaian pengelolaan hutan lestari di

Kabupaten Hulu Sungai Selatan sejalan dengan komitmen Pemkab Hulu

Sungai Selatan untuk mewujudkan tata kelola hutan yang sesuai fungsi dan peruntukkan serta mewujudkan proses transpormasi dan desentralisasi kelembagaan pengelolaan hutan.

Skema perlindungan hutan dalam mengurangi illegal logging dan perambahan hutan adalah dengan melakukan upaya prepentif dengan bekerjasama dengan pihak terkait Polisi kehutanan, Polri dan TNI yang diwujudkan dengan Tim Operasi Gabungan Pengamanan Hutan dan Peredaran Hasil Hutan dengan pelaksanaan berkesinambungan dan pelibatan masyarakat secara swadaya untuk menjaga hutan melalui Kelompok Pengawas Masyarakat (Pokwasmas). Tahun $2014 \quad$ KPHL Model HSS telah memprakarsai Tim Gabungan Pengamanan Hutan dengan diterbitkannya Surat keputusan Bupati
Hulu Sungai Selatan Nomor 50 Tahun 2014 dan membina 5 (lima) Kelompok Pengawas Masyarakat (pokwasmas) di 5 Desa yang secara swadaya menjaga hutan diwilayahnya.

Perlindungan hutan dari perambahan difokuskan pada penyelesaian masalah status lahan didalam kawasan hutan yang berubah peruntukkanya, dengan melakukan pendekatanpendekatan sosial psikologis masyarakat dan memberikan alternative model pelibatan pengelolaan hutan masyarakat dengan model Hutan Kemasyarakatan (HKm) dan Hutan Desa (HD) serta pola kemitraan. Pada Kecamatan Padang Batung terdapat \pm $1.075 \mathrm{Ha}$ lahan dalam kawasan hutan lindung yang sudah ditetapkan Pencadaangan Areal Kerja (PAK) oleh Menteri Kehutanan dan 12. 850 Ha usulan Hutan Kemasyarakatan dalam hutan lindung $2.390 \mathrm{Ha}$ dalam hutan produksi yang terdiri dari 3 Kecamatan (Padang Batung,Loksado dan Telaga Langsat) yang ada dalam kawasan kelola KPHL Model HSS serta terdapat 750 Ha usulan Hutan Desa di Kecamatan Loksado.

Kabupaten Hulu Sungai Selatan dilalui 63 sungai, besar dan kecil. Panjang sungai secara keseluruhan yang melalui Kabupaten Hulu Sungai Selatan adalah sepanjang 522,957 Km yang secara total mengalirkan 919,392 m3 air per detik. Selain sungai, di Kabupaten Hulu Sungai Selatan juga terdapat danau besar dan kecil yang menjadi kawasan suaka perikanan.

Sungai-sungai ini mempunyai peranan yang cukup penting dalam perhubungan sungai dan pertanian. Di Kabupaten Hulu Sungai Selatan, sungai juga digunakan masyarakat untuk keperluan sehari-hari seperti untuk mandi dan cuci.

Analisis terhadap tekanan yang muncul, kondisi eksisting yang terjadi berikut dampaknya serta respons yang dilakukan kemudian dikenal sebagai 
pendekatan PSR (Pressure - State Respons) seperti terlihat dalam diagram alir pada Gambar di bawah ini.

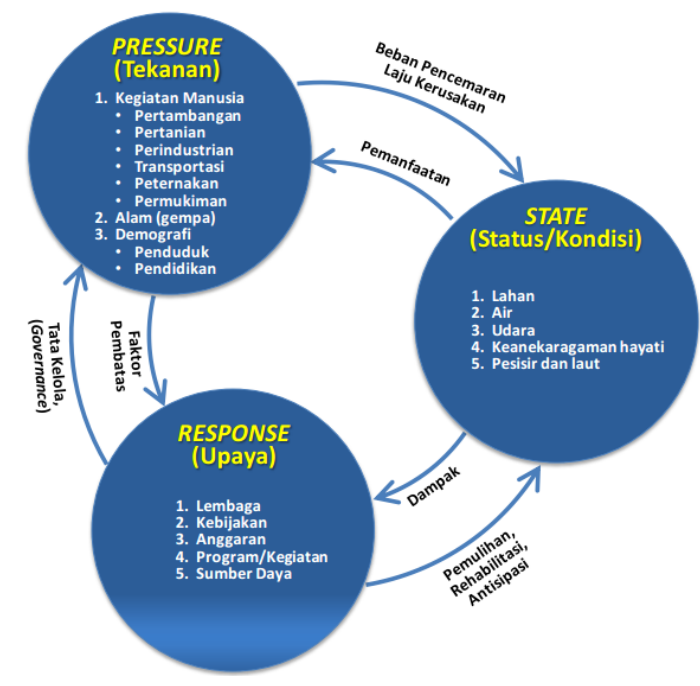

Sumber: UNEP dengan modifikasi

Gambar 1. Diagram Model PSR (TekananStatus-Respon)

Tekanan terhadap lingkungan hidup meliputi aktivitas seperti konsumsi energi, transportasi, industri, pertanian, kehutanan dan urbanisasi. Tekanan juga meliputi interaksi-interaksi berikut:

a. Lingkungan hidup sebagai sumber aktivitas ekonomi manusia seperti mineral, makanan dan energi. Dalam prosesnya berpotensi mengurangi (depleting) sumber-sumber daya tersebut atau mengganggu ekosistem.

b. Aktivitas manusia memberikan dampak negatif berupa polutan (sampah/limbah) dan kerusakan lingkungan hidup.

c. Kondisi lingkungan hidup seperti udara, air, dan sumber pangan yang tercemar mempunyai dampak langsung terhadap kesehatan manusia dan kesejahteraan.

Tekanan ini akan mengubah kondisi lingkungan hidup, yang pada gilirannya kembali mempengaruhi kesejahteraan manusia itu sendiri. Kondisi lingkungan hidup ini meliputi kualitas air, udara, lahan, ketersediaan sumber daya alam, keanekaragaman hayati. Respon masyarakat terhadap perubahan ini pada tingkat yang berbeda dapat berbentuk peraturan, teknologi, dan peningkatan kapasitas lainnya.
Rendahnya cakupan air bersih di perdesaan banyak dipengaruhi oleh kondisi alam. Ada beberapa wilayah di Kabupaten Hulu Sungai Selatan yang merupakan daerah rawa yang meliputi Kecamatan Daha Utara, Daha Barat, Daha Selatan, sebagian Kecamatan Kalumpang dan sebagian Kecamatan Simpur. Kondisi air rawa yang banyak mengandung zat besi $(\mathrm{Fe})$ tidak layak dijadikan air baku, selain itu butuh biaya besar untuk mengolahnya. Hal juga yang menyebabkan sambungan air perpipaan dari PDAM untuk wilayah-wilayah tersebut terbatas. Kondisi ini diperparah dengan budaya masyarakat yang terbiasa menggunakan air sungai yang tidak layak konsumsi untuk keperluan sehari-hari.

Terdapat 5 sungai yang diambil sample airnya untuk diketahui kualitasnya. Kelima sungai tersebut adalah Amandit, Kalumpang, Amandit, Telaga Langsat dan Negara. Hasil uji laboraturium menenunjukkan bahwa terdapat beberapa titik sungai yang kualitas airnya melebihi baku mutu standarnya. Lokasi - lokasi tersebut adalah:

- Pada Sungai Amandit kadar Residu Tersuspensi (TSS) melebihi baku mutu di lokasi sebelah Outlet Pertambangan Ds. Malutu Kec. Padang Batung

- Pada Sungai Amandit kadar COD melebihi baku mutu di lokasi Jl. Muara Banta Dalam (sebelum Intake PDAM), Ds. Malilingin Kec. Padang Batung dan Ds. Malutu Bendungan/ Irigasi Amandit

- Pada Sungai Amandit kadar Besi (Fe) melebihi baku mutu di lokasi Jl. Muara Banta Dalam (sebelum Intake PDAM)

- Pada Sungai Kalumpang kadar BOD, COD, DO, Besi (Fe), dan Mangan (Mn) melebihi baku mutu di lokasi Ds. Balanti Kec. Kalumpang

- Pada Sungai Amandit kadar Residu Tersuspensi (TSS), COD dan Besi 
(Fe) melebihi baku mutu di lokasi wilayah Pandai Getah (belakang 3R) Kel. Kandangan Barat Kec. Kandangan

- Pada Sungai Telaga Langsat kadar COD, DO dan Besi (Fe) melebihi baku mutu di lokasi Ds. Telaga Langsat Kec. Telaga Langsat

- Pada Sungai Negara kadar COD, DO dan Besi (Fe) melebihi baku mutu di lokasi (Terminal Perhubungan) Ds. Tumbukan Kayu Kec. Daha Selatan

Pada wilayah Kabupaten Hulu Sungai Selatan terdapat Danau Bangkau dengan kadar DO dan Besi (Fe) melebihi baku mutu di lokasi Ds. Bangkau Kec. Kandangan.

Kualitas air sumur yang dianalisa pada 6 titik lokasi diketahui bahwa pada lokasi Pesantren Tarbiyatul Furqon Kel. Jambu Hilir Kec. Kandangan dan Ds. Tambikar Kec. Kalumpang memiliki kandungan Besi (Fe) yang melebihi baku mutu standar. Selain itu pada lokasi Ds. Gambah Dalam Barat Kec. Kandangan memiliki kandungan $\mathrm{pH}$ dibawah baku mutu standar.

Penurunan kualitas air adalah masih ditemui adanya penduduk yang buang air besar di sungai sejumlah $21.945 \mathrm{KK}$ yang tersebar di semua kecamatan dan akan mempengaruhi kualitas air sungai tersebut. Namun demikian, sudah terdapat KK yang mau untuk menggunakan sarana buang air besar secara bersama, yaitu di Kecamatan Padang Batung, Simpur dan Daha Selatan sejumlah 469 KK.

Pelayanan air minum untuk wilayah Kabupaten Hulu Sungai Selatan di wilayah perkotaan dilayani oleh PDAM dan di wilayah perdesaan masih menggunakan air minum non perpipaan dengan sumber air berasal dari sumur, sungai dan mata air lainnya. Sumber air minum rumah tangga yang terbesar adalah bersumber dari air sungai $(30,57 \%)$, kemudian sumur pompa $(28,20 \%)$ baru air bersih PDAM sebesar $25,97 \%$.

PDAM bukan merupakan satusatunya sumber air minum yang ada di Kabupaten Hulu Sungai Selatan dan terdapat sumber lainnya, yaitu: ledeng, sumur, hujan dan lainnya. Data yang diperoleh menunjukkan bahwa sumber air minum yang paling banyak adalah sumber lainnya sebanyak 63.600 rumah tangga.

Untuk meningkatkan cakupan pelayanan air bersih terutama di perdesaan pemerintah Kabupaten Hulu Sungai Selatan berusaha memanfaatkan sumber air yang ada untuk dapat diakses oleh masyarakat salah satunya melalui Program PAMSIMAS yang telah dilaksanakan sejak tahun 2008. Sedangkan untuk daerah perkotaan pelayanan air bersih dilaksanakan oleh PDAM, dengan Daerah pelayanan BNA Kota Kandangan meliputi wilayah pelayanan sebagai berikut: Kandangan Kota, Kandangan Utara, Kandangan Barat, Kandangan Selatan, Kandangan Timur dan Sungai Raya.

\begin{tabular}{lccr}
\multicolumn{2}{c}{ Disamping itu } & juga & terdapat \\
daerah & pelayanan & diluar & batas \\
administrasi & dan & tentatif & Kota \\
Kandangan. & Hal ini & terjadi & karena
\end{tabular} adanya interkoneksi sistem jaringan distribusi dengan beberapa IKK yang menyebabkan meluasnya wilayah pelayanan BNA Kota Kandangan. IKK yang termasuk kedalam wilayah pelayanan BNA Kota Kandangan adalah sebagai berikut :IKK Padang Batung, IKK Angkinang - Telaga Langsat, IKK Kalumpang, IKK Simpur - Sungai Raya.

\section{SIMPULAN}

Dari permasalahan di atas dan sebagai upaya pengelolaan lingkungan maka simpulan yang dihasilkan adalah masih adanya penggunaan air sungai untuk kegiatan Mandi Cuci Kakus (MCK) sehingga diperlukan suatu upaya untuk /mengurangi pemakaian air sungai untuk aktivitas MCK, atau dengan kata lain menghapuskan atau mengurangi jumlah jamban di atas sungai. Menghimbau masyarakat untuk tidak lagi membangun/ menggunakan jamban di atas sungai, dan menghimbau masyarakat yang tinggal di daerah sempadan sungai untuk membangun 
fasilitas MCK dengan menggunakan septic tank, ataupun IPAL komunal. Mengurangi/menghentikan kebiasaan masyarakat untuk membuang limbah baik limbah padat maupun limbah cair ke sungai. Menghimbau masyarakat, khususnya petani untuk menggunakan pupuk kimia/buatan secara lebih bijaksana, atau sesuai dengan keperluan dan tidak berlebihan. Bahkan, jika memungkinkan, mengganti pupuk kimia dengan pupuk alami seperti pupuk kandang atau kompos. Masih dijumpai penebangan hutan liar sehingga berakibat pada kerusakan lahan dan tutupan lahan yang nantinya berakibat pada penutrunan kualitas lingkungan air, udara.untuk mengantisipasinya maka diperlukan upaya untuk tetap melakukan pemeliharaan pada kawasan hutan dan tutupan lahan dengan harapan kuantitas dan kualitas air tetap terjaga

\section{DAFTAR PUSTAKA}

Badan Penanggulangan Bencana, Kesbangpol Kabupaten Hulu Sungai Selatan, 2017

BPS Kabupaten Hulu Sungai Selatan dalam Angka Tahun 2017

Perda Nomor 3 Tahun 2014 tentang RTRW Kabupaten Hulu Sungai Selatan Tahun 2013 - Muhidin, D., 2001, Papain dan Pektin, Penerbit Swadaya, Jakarta

Surat keputusan Bupati Hulu Sungai Selatan Nomor 50 Tahun 2014 Pembentukan Tim Gabungan Pengamanan Hutan dengan diterbitkannya

Undang-Undang nomor 32 tahun 2009 tentang Perlindungan dan Pengelolaan Lingkungan Hidup 